\title{
Open Type Tasks in Mathematics as a Tool for Students' Meta-Subject Results Assessment
}

\author{
Nadezhda P. Yachina \\ Kazan Federal University, RUSSIA \\ Pavel M. Gorev \\ Vyatka State University of Humanities, RUSSIA \\ Aygerim K. Nurgaliyeva \\ Pavlodar State Pedagogical Institute, RUSSIA
}

•Received 17 June 2015• Revised 22 August 2015•Accepted 19 September 2015

The relevance of the present study is due to the tasks of assessing the quality of secondary education, which determine students' subject knowledge along with their personal achievements, and where meta-subject skills define not only the level of educational results achieved, but also the prospects for the future high-quality training for a school graduate at any age. Thus, the purpose of the study conducted is to create approaches for making the system of tasks together with the criteria of their assessment to determine the level of students' meta-subject results. The leading methods applied are modeling systems of open type tasks, with mathematical content and systematic analysis of large samples of experimental data, based on the evaluation of the two-point scale four parameters: the optimality of students' proposed ideas, efficiency of reasoning, originality of their answer and development degree of their solutions. A pilot study conducted since 2008 has applied open tasks with mathematical content and the criteria for their assessment formed the approach to determine the level of high school students' meta-subject results, expressed quantitatively in the form of an integrated assessment of the relative character - meta-subject intelligence quotient. Practical use of the intelligence quotient enables the making of accurate calculations for each age group in order to show the level of students' meta-subject results. This in turn may determine the future direction of students' individual development, and to ensure their transition to a higher level of meta-subject skills and, consequently, higher quality of education.

Keywords: education quality assessment, meta-subject approach, open type tasks, the criteria of open type tasks assessment, intelligence quotient

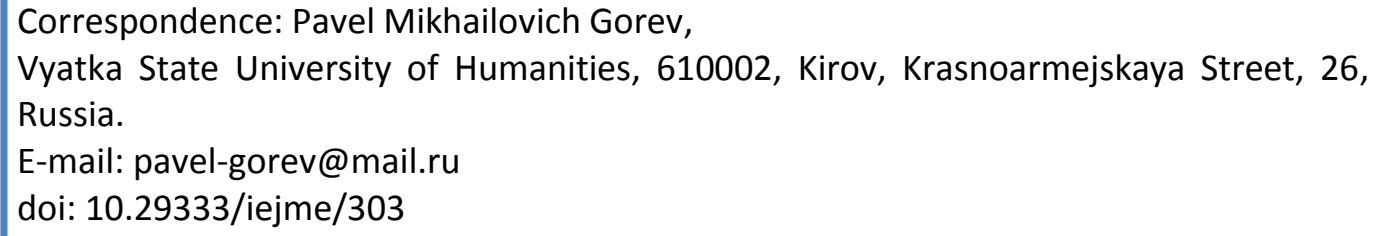




\section{INTRODUCTION}

\section{Relevance of the study}

Quality control improvement and quality management have become the areas of modernization of the Russian educational system. In the government-approved development priorities of the educational system of the Russian Federation, it is noted that there is a need to form a national system for evaluating the quality of education received by each citizen (Government of the Russian Federation, 2008). However, among Russian authors working on this problem (Bolotov, 2005; Zheleznova, 2014; Kolomiets, 2003; Subbeto, 2004; Tretyakov, 2002), there is no common point of view on the number of "quality criteria" or their quality indicators. According to Bolotov, "evaluation of the quality of education implies the assessment of the quality of educational achievements of students and the evaluation of the quality of the educational process. The quality of education is understood as an integral characteristic of the educational system, which reflects the extent of compliance of the actual achieved educational results with both the regulatory requirements and social and personal expectations" (Bolotov, 2014). In our opinion, building the national system of assessment of educational quality according to priority directions of development of the educational system of the Russian Federation should be based on two aspects: 1) experiences from international research on evaluating the quality of education, and 2) normative regulation of intended educational results achieved by school students.

\section{International scientific research on educational quality assessment}

Today, international research groups such as Program for International Student Assessment (PISA), Trends in Mathematics and Science Study (TIMSS), and International Assessment of Educational Progress (IAEP), study the problem of educational quality assessment. The research groups determine the quality of education as students' mastery of reading, mathematical, scientific, information and computer literacy. Students from educational institutions of Russia were actively involved in these studies, but the results of independent educational quality assessment were considered with indifference. At the same time, the foreign experience in this field can be hardly overestimated, for example, France (research group PISA), the USA (IAEP), Netherlands (TIMSS), and Germany (PIRLS) (Site of Center for Educational Quality, 2014).

Considering the conceptual model of one of the foreign studies (Figure 1), one can see that there are common approaches to the assessment of educational achievement on the subjects and common cognitive activities, which students should show while solving tasks (The main results of an international study of quality of mathematical and natural science education TIMSS-2011, 2013). In our opinion, the Russian educational system fixes typical cognitive activities for task solution.

\section{The regulatory framework of intended educational results of high school students}

The present federal state educational standards of general education specify the requirements for the learning results of basic educational programs of primary, secondary and secondary general education. These requirements should be taken into account while developing the system of educational quality assessment. The current educational standards of the new generation strengthens their focus on the educational results as a backbone component of standards. These standards are designed to resolve the key contradiction of modern education - contradiction between knowledge and abilities of each student to master only a part of this 


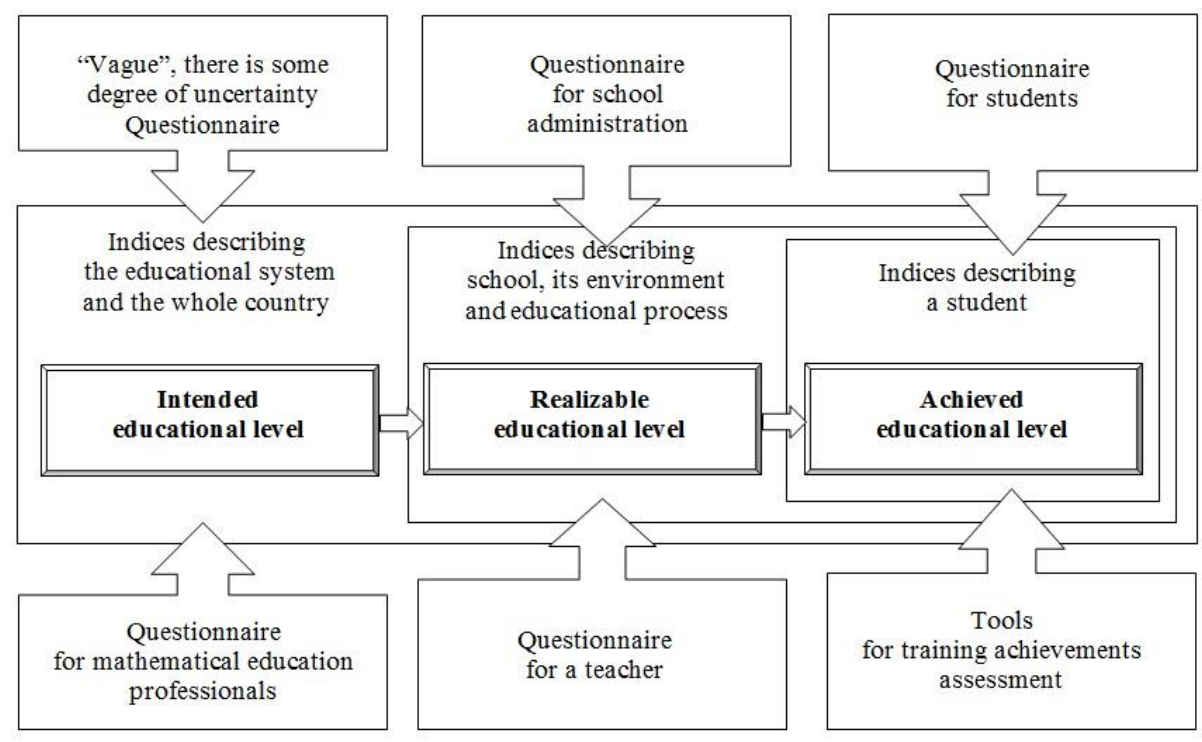

Figure 1. Conceptual Model of Research Group TIMSS

knowledge. Therefore, the federal state educational standards implies the focus on students' achievements, both in subject and meta-subject educational results (Russian Academy of Education, 2008). The standards specify requirements for personal, meta-subject and subject results of students, who have mastered the basic educational program of general education. Standards methodically worked out within the framework of general education are applied to assess subject results (i.e. evaluation of students' knowledge and skills). Psychological and social pedagogic diagnostic methods assess the personal results. These methods are methodologically worked out and repeatedly improved. Meta-subject results are a relatively new phenomena in the Russian educational system, so the evaluation system of metasubject results has neither been worked out, nor put into practice.

\section{MATERIALS AND METHODS}

\section{Methods of the study}

The study applies the following methods: analysis of the regulatory documents; analysis of psychological, pedagogic and methodological sources; analysis of learning products; method of mental experiment; forecasting; synthesizing of facts and concepts; modeling, project method, method of expert judgment; analysis of the educational activities results; study and generalization of the experience of application of open type tasks with mathematical content, diagnostic methods; and pedagogical experiment.

\section{Experimental base of the study}

The experimental work was conducted in three ways, which tested the system of open type tasks with mathematical content:

1) Participation of students (grades 1-11) in heuristic competitions "Owlet" and "Breakthrough" (Student numbers: 2008 - 1,942; 2009 - 4,228; 2010 - 6,530; 2011 16,981; 2012 - 24,020; 2013 - 48,005; 2014 - 41,470; 2015 - 33,840);

2) Participation of students (grades 1-6) in distance learning courses (Courses: 2009-2010, "Learning with the Owlet"; 2010-2011, "Journey to the Land of Creativity"; 2011-2012, "The Owlet's Magic Dreams", "Summer Tour with the Owlet"; 2012-2013, "Expedition to the World of Creativity", "The Owlet's Summer Investigation"; 2013-2014, "Creative Walks under the Stars", "The Owlet's summer 
discoveries"; 2014-2015, "The Owlet's Fascinating Voyage", "The Owlet's Summer Trip"). The total number of participants was 10,543 students;

3) Participation of students (grades 5-9) on training courses held in educational institutions (2,132 students).

The experimental work involved students of all age groups from secondary schools in all regions of the Russian Federation and some neighboring countries.

The study was conducted in three stages:

1) The "preparatory" stage. Analysis of the current state of the investigated problem in pedagogical theory and practice, and the development of research methodology;

2) The "main" stage. Development and implementation of open type tasks with mathematical content; the systematic analysis of large samples of the experimental data; verification of the methodology effectiveness for assessing the level of students' meta-subject skills formation;

3) The "final" stage. Systematization, interpretation and synthesis of the research results; refinement of the theoretical conclusions; processing and registration of the obtained results.

\section{RESULTS}

\section{Meta-subject results and the problem of their assessment}

We can conclude that the international experience in educational quality assessment and the requirements of the educational standards narrow the problem of educational quality assessment to assessment of meta-subject results.

Meta-subject results include the level of students' knowledge of interdisciplinary concepts and universal training activities (regulatory, cognitive and communicative); students' ability to use the knowledge in cognitive and social practice; autonomy in planning and implementation of educational activity and organization of educational cooperation with teachers and contemporaries; the ability to build individual educational trajectory; possession of learning-research, project and social skills (Kovalenko \& Nikitin, 2013).

Thus, meta-subject achievements in general education are based on interdisciplinary concepts and universal learning activities. Universal learning activities can be evaluated as foreign research by recording several cognitive activities. Only "non-subject" tasks can implement the assessment of interdisciplinary concepts. This assessment requires the special tasks, which are not reduced to the subject knowledge.

\section{Open type tasks as a tool of meta-subject results assessment}

Below we describe the task of the series "Mathematics", as proposed in the framework of international research, TIMSS.

Task 1. Here are two shapes. Describe their similarities and differences (Figure 2).

The problem has a vague condition that does not determine the exact sequence of actions. Such tasks are generally called open type tasks (Gorev \& Utemov, 2011). In our opinion, such tasks can act as a tool to assess the level of formation of metasubject skills (Zinovkina, Gareev, Gorev, \& Utemov, 2013).

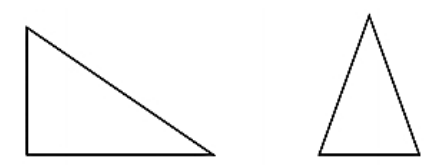

Figure 2. Illustration of the task proposed by TIMSS 
Below we consider the difference between open type and closed type tasks (Utemov, Zinovkina, \& Gorev, 2013).

Closed type tasks provide clear and unambiguous interpretation of problem conditions. As a result, the task usually has the one correct solution. Such tasks do not give the student an opportunity to form an integral meta-subject quality (Figure 3).

The following task is an example of the closed type task:

Task 2. To paint $1 \mathrm{~m}^{2}$ of ceiling you need 240 grams of paint. The paint is sold in cans weighing $2.5 \mathrm{~kg}$ each. What is the minimum amount of cans you need to buy to paint the $50 \mathrm{~m}^{2}$ ceiling?

Tasks of this type are didactically valuable in practicing any particular solution method or in acquaintance with new material. These tasks are based on ready facts and knowledge; for their solution students obtain comprehensive information about the solution method, conditions, and sometimes the answer, the accuracy of which is not doubtful.

Below we consider the task of open type. The characteristics of its basic parameters are determined in Figure 4.

The following task is an example of the open type task:

Task 3.You probably noticed that the larger pits and ditches that have to be overcome by a vehicle, the greater the diameter of the wheels. For example, a tractor that works the fields. Racing cars, on the other hand, have small wheels in order to drive faster on the perfect road. Is it possible to come up with a universal wheel, which would change its size depending on the condition of the road?

Open type tasks have indistinct conditions, hence it is unclear how to act, or what to use in the solution. However, the desired result is clear. These tasks require a variety of solutions that are not straight; moreover you have to overcome obstacles encountered. There are a lot of options for solutions, but there is no concept of the

Condition

Condition clearly provides all necessary data
Solution

Solution method known; formal actions chain
Answer

Correct answer is uniquely defined

Figure 3. The structural scheme of closed type tasks

Condition

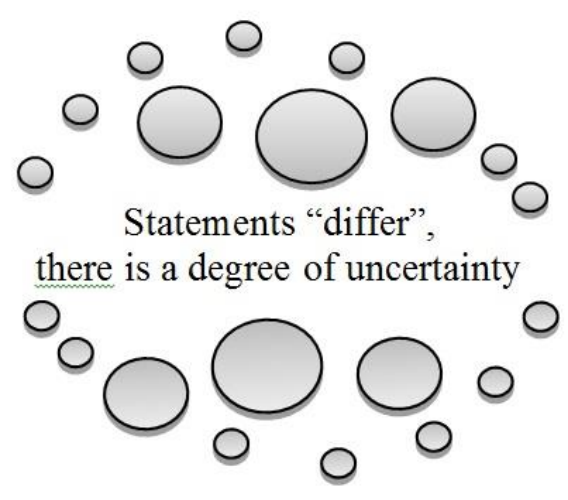

Solution

Solution methods may vary

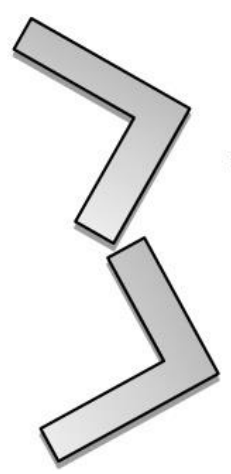

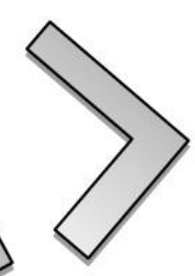

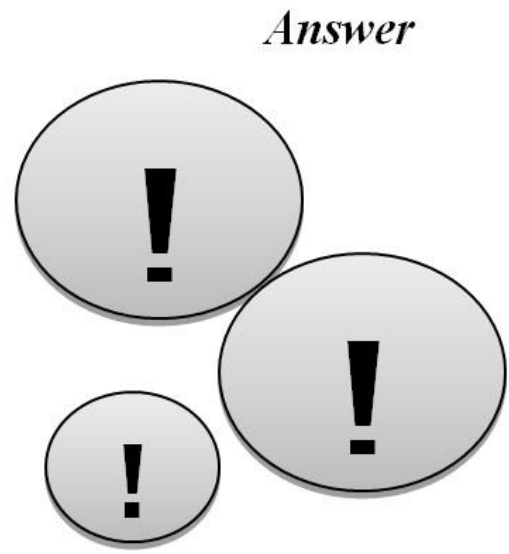

The set of possible answers

Figure 4. The structural scheme of open type tasks 
right one, because it should already have been applied in order to achieve the desired results, or not. Open type tasks give possibility to apply standard knowledge in a nonstandard situation. Carrying out the tasks the student can demonstrate the ability of logic and abstract thinking that is the ability to categorize, summarize and draw analogies, to predict the result applying intuition, imagination, and fantasy. The most important is that these tasks contribute to the formation of an integral meta-subject quality.

The division of tasks into closed and open types has vague outlines; the task is not always accurately referred to the problem of a particular type. For this reason, it is advisable to consider partially open type tasks. In school practice, partially open type tasks are presented as creative tasks. In these tasks, condition, solution and answer (together or separately) have closed characters. Thus, partially open type tasks have boundary position and they are often used on the reproductive level of learning educational material.

\section{Classification of partially open type tasks with mathematical content}

Below we give the example of classification of partially open type tasks, determined in the process of analysis of educational sources (Table 1) (Mikhaylov, Gorev, \& Utemov, 2014).

Table 1. Classification of partially open type tasks

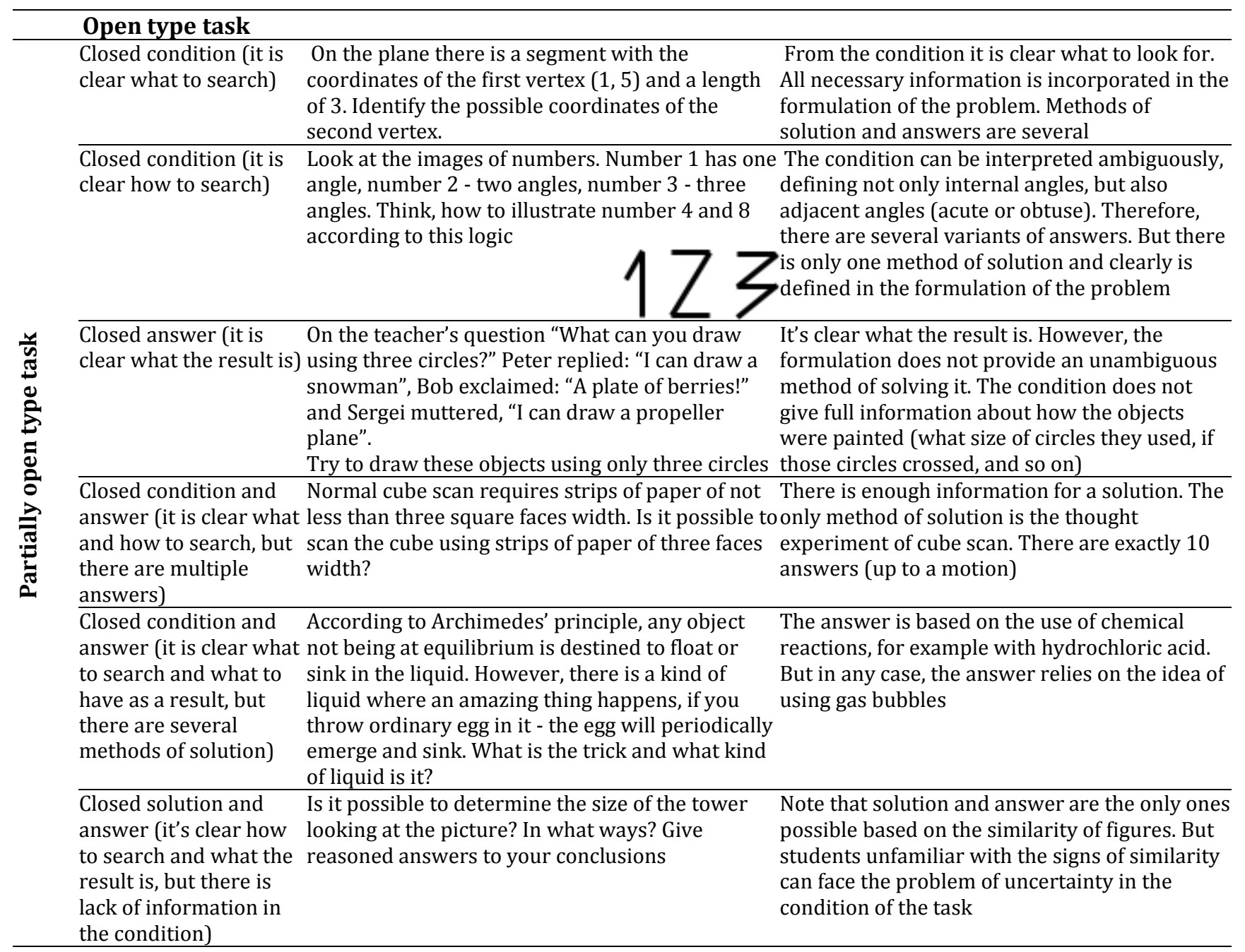

\section{Closed type task}




\section{Criteria for open type tasks assessment}

To determine the level of formation of meta-subject character of the results, approved criteria for evaluating educational open type tasks can be used, obtained on the basis of creativity indicators' generalization by Guilford and Torrance (Guilford, 1967; Torrance, 1964) (Table 2)

Thus, assessment criteria of the open type tasks define an eight-point scale. It characterizes the level of students' meta-subject results manifestation in mastering the programs.

The open type tasks system consists of six tasks directed to various types of cognitive activity. Evaluation of the open type tasks solutions may be an indicator of quantitative index of students' meta-subject achievements formation. The accuracy of estimating the level of students' meta-subject manifestation may be taken into account only according to numerous practices of carefully selected open type tasks. The total score of the six tasks can be considered as the final level of creativity.

\section{Meta-subject intelligence quotient, based on the evaluation criteria of open type tasks}

We analyzed the results of our own research conducted in 2008 within the heuristic competitions "Owlet" and "Breakthrough" and other forms of work based on open type tasks. The investigation of more than 200,000 students from various Russian regions and abroad shows that such systems may be considered as a mean of meta-subject results' evaluation in mastering basic educational programs of general education. To adjust the results, you can use the integrated assessment of the relative character - meta-subject intelligence quotient.

By analogy with the intelligence tests (such as IQ), intelligence quotient represents the ratio of "mental age" to the actual chronological age of the subject. Calculation of the intelligence quotient is carried out separately for each age group according to the common division of participants' scores. About $50 \%$ of participants should have the confidence interval 90-110 test scores (up to equal points); about 25\% of participants should have the result below 90 test scores and another $25 \%$ of participants - higher than 110 test scores showed (up to equal points) (Figure 5).

It should be noted that according to the description of the methodology of foreign studies, scales on specific informative categories and types of cognitive activity also have comparable parameters: average value of the average scores of all countries participating in the study is taken as 500, with a standard deviation 100 .

Table 2. Criteria for open type tasks assessment

\begin{tabular}{|c|c|c|c|c|}
\hline Marks & $\begin{array}{c}\text { Effectiveness } \\
\text { (Was the required task } \\
\text { achieved?) }\end{array}$ & $\begin{array}{l}\text { Optimality } \\
\text { (Is such a decision } \\
\text { justified, or not?) }\end{array}$ & $\begin{array}{c}\text { Originality } \\
\text { (Is the decision new or } \\
\text { previously known?) }\end{array}$ & $\begin{array}{c}\text { Status } \\
\text { (Is the solution } \\
\text { detailed, or at the level } \\
\text { of ideas?) }\end{array}$ \\
\hline 2 & $\begin{array}{l}\text { The proposed solution will } \\
\text { give clear understanding on } \\
\text { how to achieve results }\end{array}$ & $\begin{array}{l}\text { The solution has a } \\
\text { particular method } \\
\text { providing a quite capacious, } \\
\text { clear and optimal result }\end{array}$ & $\begin{array}{l}\text { Solution is original, and is } \\
\text { found with }<5 \% \text { of } \\
\text { respondents }\end{array}$ & $\begin{array}{l}\text { Solution is reasoned clearly } \\
\text { and correctly and all actions } \\
\text { are justified }\end{array}$ \\
\hline 1 & $\begin{array}{l}\text { All in all, the solution process } \\
\text { is clear and it is possible to } \\
\text { achieve the results, but some } \\
\text { elements of the solution are } \\
\text { not thought out or vaguely } \\
\text { explained }\end{array}$ & $\begin{array}{l}\text { The solution is optimal, } \\
\text { but some aspects of the } \\
\text { solution process can be } \\
\text { greatly simplified }\end{array}$ & $\begin{array}{l}\text { The solution is rarely found } \\
\text { in the answers: between } 5- \\
10 \% \text { of respondents }\end{array}$ & $\begin{array}{l}\text { The decision is on the level } \\
\text { of ideas that might be } \\
\text { brought to reasonable } \\
\text { justification and completion }\end{array}$ \\
\hline $\mathbf{0}$ & $\begin{array}{l}\text { According to the solution, it is } \\
\text { not clear how to achieve the } \\
\text { desired result }\end{array}$ & $\begin{array}{l}\text { The solution process is too } \\
\text { cumbersome; the use of } \\
\text { many techniques are } \\
\text { unjustifiable }\end{array}$ & $\begin{array}{l}\text { The solution is standard } \\
\text { and provided by more } \\
\text { than } 10 \% \text { of respondents }\end{array}$ & $\begin{array}{l}\text { The solution process is not } \\
\text { represented or is vague }\end{array}$ \\
\hline
\end{tabular}


So, basing on the analysis of 33,840 participants' works of competitions held in 2015 , the trends in the assessment of meta-subject intelligence quotient were identified. As a result, the participants were divided into four groups. The number of participants who fell into the first group, each parallel is the maximum, but not exceeding the level of $10 \%$ of the total number of participants in this parallel up to equal points. The number of participants who fell into the second group is determined by the intelligence quotient: this group includes participants with test scores above the level of 110 points, but not included in the first group. The number of participants belonging to the third group is determined by confidence interval of sample according to intelligence quotient of $90-110$ points. The other participants are in the fourth group of points (Table 3 ).

Thus, the integration result of the open type tasks is closely linked to the development of students' meta-subject results of basic educational programs. Metasubject intelligence quotient may be used for meta-subject assessment, reflecting the general human ability to express the cognitive activity of the subject and his ability to assimilate new knowledge, action, complex forms of activity. In this regard, we believe that the use of meta-subject intelligence quotient in assessing learning outcomes will enhance the effectiveness of education and the creation of conditions for the formation of subject teaching models in secondary school. We believe that further research can be continued towards the development of open type tasks with the

90 points $\quad 100$ points $\quad 110$ points

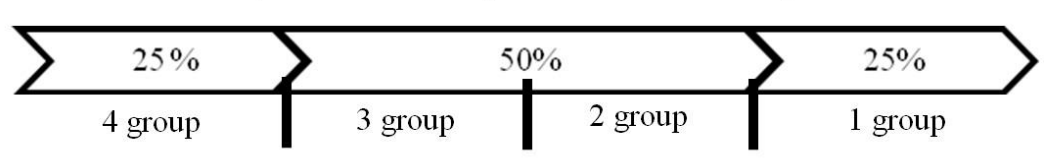

Figure 5. Meta-subject intelligence quotient

Table 3. Participant groups division based of scores of meta-subject intelligence quotient

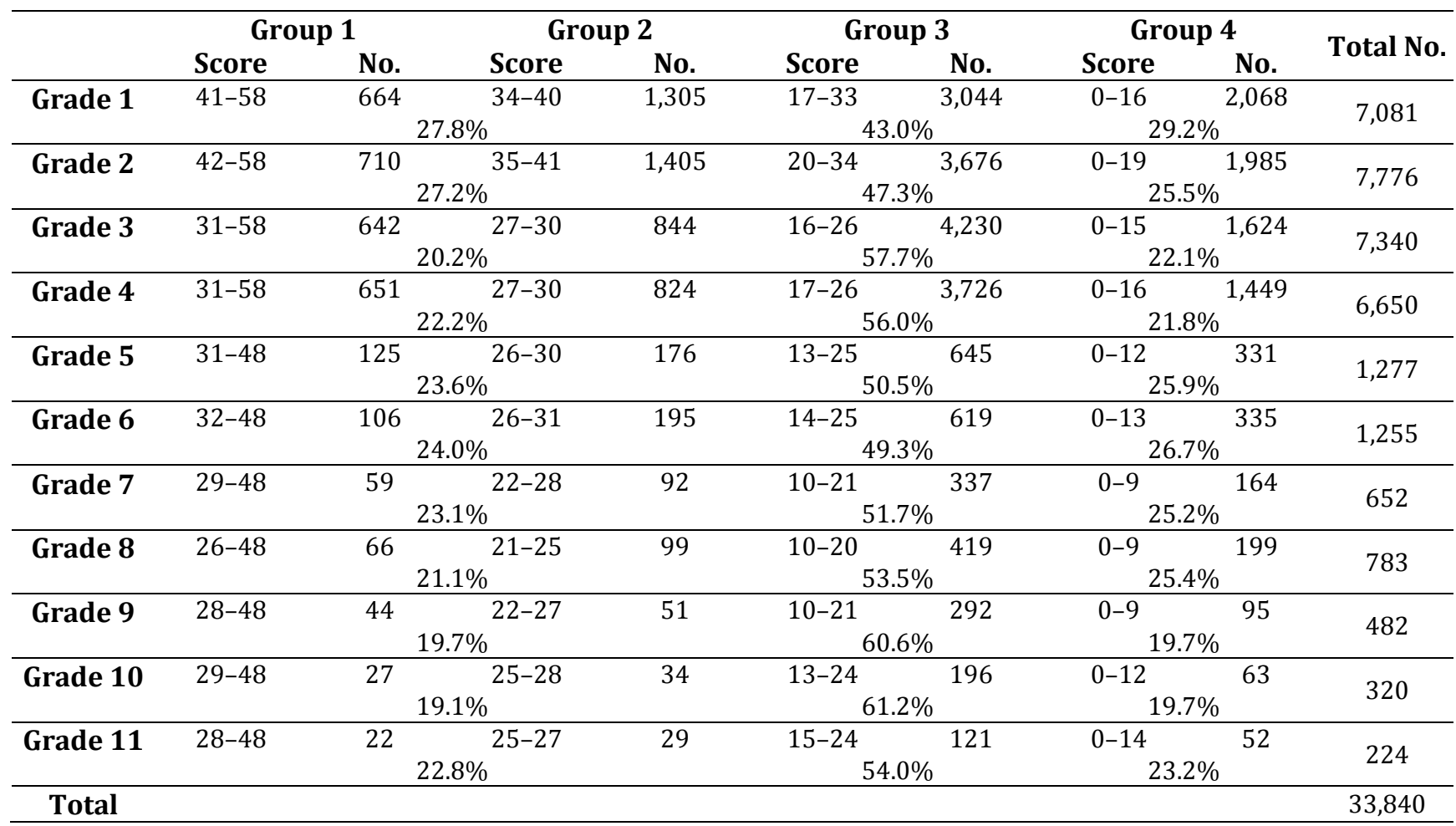


assessment of each type of universal educational actions and the selection of criteria

Table 4. International programs for assessing the quality of education

\begin{tabular}{|c|c|c|c|}
\hline Program & Characteristics & Areas/subjects & Grade \\
\hline $\begin{array}{l}\text { PISA - Program for International } \\
\text { Student Assessment }\end{array}$ & $\begin{array}{l}\text { Program for International Student Assessment - a test } \\
\text { that assesses literacy of students in different countries } \\
\text { and the ability to apply knowledge in practice }\end{array}$ & $\begin{array}{l}\text { Reading literacy; } \\
\text { Mathematics, Sciences and } \\
\text { IT literacy }\end{array}$ & 8 \\
\hline $\begin{array}{l}\text { TIMSS - Trends in Mathematics } \\
\text { and Science Study }\end{array}$ & $\begin{array}{l}\text { International monitoring of quality level of school } \\
\text { mathematics and science education }\end{array}$ & Mathematics, Sciences & $4 ; 8$ \\
\hline $\begin{array}{l}\text { ICILS - International Computer } \\
\text { and Information Literacy Study }\end{array}$ & International Computer and Information Literacy Study & $\begin{array}{l}\text { Computer and Information } \\
\text { Literacy }\end{array}$ & 8 \\
\hline $\begin{array}{l}\text { PIRLS - Progress in International } \\
\text { Reading Literacy Study }\end{array}$ & $\begin{array}{l}\text { International study of reading literacy and } \\
\text { understanding texts }\end{array}$ & $\begin{array}{l}\text { Reading literacy and } \\
\text { understanding texts }\end{array}$ & 4 \\
\hline $\begin{array}{l}\text { CIVIC - International Association } \\
\text { for the Evaluation of Education } \\
\text { Achievements }\end{array}$ & International study of sociology & Sociology & 9 \\
\hline $\begin{array}{l}\text { IAEP - International Assessment } \\
\text { of Educational Progress }\end{array}$ & $\begin{array}{l}\text { Comparative evaluation of the quality of training high } \\
\text { school students }\end{array}$ & $\begin{array}{l}\text { Mathematics, Natural } \\
\text { History }\end{array}$ & $4 ; 8$ \\
\hline $\begin{array}{l}\text { Control measuring materials of } \\
\text { the Russian Academy of } \\
\text { Education }\end{array}$ & $\begin{array}{l}\text { Control measuring materials to assess the training of } \\
\text { primary school leavers }\end{array}$ & $\begin{array}{l}\text { Mathematics, Russian } \\
\text { language, Nature Study }\end{array}$ & 4 \\
\hline
\end{tabular}

for its evaluation.

\section{DISCUSSIONS}

Assessment of the quality of education through the evaluation of cognitive activities for quite a long time has been carried out at the international level. Summarized data of international studies' areas to assess the quality of education are given in Table 4.

Russian scholars working on the problem include Bolotov (2005), Zheleznova (2014), Kolomiets (2003), Subbeto (2004), and Tretyakov (2002). However, analysis of scientific papers on the topic showed that modern views on the evaluation of the quality of education through students' achievement of meta-subject results have not been thoroughly studied, as the authors do not offer mechanisms for assessing students' achievements.

\section{CONCLUSION}

It was found that the result of the pilot study (held since 2008) using open type tasks with mathematical content and the criteria for their assessment is the new approach to determination of the level of students' achievement of meta-subject results, expressed quantitatively in the form of integrated assessment of the relative character - meta-subject intelligence quotient. It is based on the criteria of open-type tasks estimation (optimality of the proposed ideas of students, effectiveness of their reasoning, originality of their answer and degree of elaboration of their decisions). Specially selected systems which indicate the level of students' achievement of metasubject results with reliable accuracy of normal distribution for each age group that in turn may determine the future direction of development of an individual student to ensure his transition to a higher level of meta-subject skills and, consequently, better quality of education.

\section{RECOMMENDATIONS}

The paper may be useful for teachers, mentors and tutors, striving to improve the level of students' achievement of meta-subject results, to evaluate and further adjust individual educational direction of students' development at the level of their meta- 
subject skills assimilation. Taking into account the results of this study, we can identify a number of scientific issues and prospective directions of further consideration: the deepening and widening of certain aspects discussed in the paper related to the accumulation of psychological and pedagogical potential of open type tasks in training; the development of scientific-methodological support for widespread use of meta-subject intelligence quotient to evaluate the level of students' achievement of meta-subject results.

\section{REFERENCES}

Bolotov, V.A. (2005). About the construction of the Russian system of education quality. Problems of education, 1, 5-11.

Bolotov, V.A. (2014). Becoming a nationwide system of education quality assessment. In the official website of the Federal Service for Supervision in Education and Science. Retrieved August 19, 2014, from http://www.obrnadzor.gov.ru/files/attest2007/46316820.doc.

Guilford, Y.P. (1967) The nature of human intelligence. N. Y.: Mc-Graw Hill.

Gorev, P.M., \& Utemov, V.V. (2011). Formula creativity: We solve an open problem. Kirov, 288.

Government of the Russian Federation. (2008). Order of the Government of the Russian Federation from 17.11.2008 No.1662-r (ed. By 08.08.2009) “On the Concept of long-term social and economic development of the Russian Federation for the period till 2020".

Kolomiets, B.K. (2003). Quality management of education: the invariant aspects. Moscow: Research center of problems of quality of training, Moscow state technological Academy.

Kovalenko, O.A., \& Nikitin, E.K. (2013). Achieving results metasubject younger students in research situations in the classroom. Elementary School: plus or minus, 6, 67-73.

Mikhaylov, V.A., Gorev, P.M., \& Utemov, V.V. (2014). Scientific Work: Methods of designing new ideas. Kirov.

Russian Academy of Education. (2008). Project of the Concept of the federal state educational standards for general education. Eds. A.M. Kondakov, \& A.A. Kuznetsov Moscow: Education. Site of Center for Educational Quality Assessment Institute of content and teaching methods of the Russian Academy of Education. Retrieved August 19, 2014, from http://www.centeroko.ru.

Subbeto, A.I. (2004). Quality of education: problems of assessment and monitoring. The head teacher, $5,3$.

The main results of an international study of quality of mathematical and natural science education TIMSS-2011. Analytical Report. (2013). Moscow: MAX Press.

Torrance, E.P. (1964) Guiding creative talent. Englewood Cliffs, WJ: Prentice-Holl, 1964.

Tretyakov, P.I. (2002). Management of the quality of education is the main direction in development of the system: the nature, approaches, problems. The head teacher, 7, 67.

Utemov, V.V., Zinovkina, M.M., \& Gorev, P.M. (2013). Pedagogy of creativity: Applied course of scientific creativity. Kirov.

Zheleznova, L.B. (2014). The effectiveness of educational activities in the field to. Retrieved August 20, 2014, from http://blank.orenipk.ru/Text/t43_1.htm.

Zinovkina, M.M., Gareev, R.T., Gorev, P.M., \& Utemov, V.V. (2013). Scientific creativity: innovative methods in the system of multilevel continuous creative education NFTM-TRIZ. Kirov.

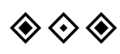

